REVIEW

This paper is dedicated to the $70^{\text {th }}$ anniversary of the founding of Physiologia Bohemoslovaca (currently Physiological Research)

\title{
The Role of AMPK/mTOR Signaling Pathway in Anticancer Activity of Metformin
}

\author{
Nikola CHOMANICOVA ${ }^{1}$, Andrea GAZOVA ${ }^{2}$, Adriana ADAMICKOVA ${ }^{3}$, Simona \\ VALASKOVA $^{1}$, Jan KYSELOVIC ${ }^{3}$
}

${ }^{1}$ Department of Pharmacology and Toxicology, Faculty of Pharmacy, Comenius University Bratislava, Slovakia, ${ }^{2}$ Institute of Pharmacology and Clinical Pharmacology, Faculty of Medicine, Comenius University Bratislava, Slovakia, ${ }^{3} 5$ th Department of Internal Medicine, Faculty of Medicine, Comenius University Bratislava, Slovakia

Received October 27, 2020

Accepted April 27, 2021

Epub Ahead of Print June 2, 2021

\begin{abstract}
Summary
Metformin (MTF) is a widely used drug for the treatment of diabetes mellitus type 2 (DM2) and frequently used as an adjuvant therapy for polycystic ovarian syndrome, metabolic syndrome, and in some cases also tuberculosis. Its protective effect on the cardiovascular system has also been described. Recently, MTF was subjected to various analyzes and studies that showed its beneficial effects in cancer treatment such as reducing cancer cell proliferation, reducing tumor growth, inducing apoptosis, reducing cancer risk in diabetic patients, or reducing likelihood of relapse. One of the MTF's mechanisms of action is the activation of adenosine-monophosphate-activated protein kinase (AMPK). Several studies have shown that AMPK/mammalian target of rapamycin (mTOR) pathway has anticancer effect in vivo and in vitro. The aim of this review is to present the anticancer activity of MTF highlighting the importance of the AMPK/mTOR pathway in the cancer process.
\end{abstract}

\section{Key words}

Antidiabetic drug $\bullet$ AMPK activation $\bullet$ Cancer therapy $\bullet$ Apoptosis - Angiogenesis

\section{Corresponding author}

A. Gazova, Faculty of Medicine, Comenius University, Špitálska 24, 81372 Bratislava, Slovakia. E-mail: andrea.gazova@fmed.uniba.sk

\section{Introduction}

Body cells have specific functions and cell death is a part of a natural phenomenon called apoptosis.
A normal cell gets orders to die but cancerous cells ignore these signals and continue to grow and divide (Vogelstein et al. 2013). The cancer process is characterized by eight phenotypical characteristics which are involved in disordered control of cell functions. These include sustained proliferative signaling, evasion of antigrowth signaling, resistance to apoptosis, limitless replicative potential, avoiding immune destruction, deregulating cellular energetics, inducing angiogenesis, and tissue invasion and formation of metastases (Block et al. 2015). A lot of cancer cells adapt to their microenvironment by aerobic glycolysis, a process known as Warburg effect, to produce energy. This metabolic reprogramming in cancer cells is regulated by many oncogenic proteins, suppressors and pathways (Abdel-Wahab et al. 2019).

Several studies in recent years have shown that metformin (MTF), a common drug used in therapy of diabetes mellitus type 2 (DM2), has anticancer effect in vivo and in vitro apparently via $\mathrm{AMPK} / \mathrm{mTOR}$ pathway ( $\mathrm{Zi}$ et al. 2017). First scientific evidence that MTF has the anticancer activity was introduced in 2001 by Schneider et al. Since then, MTF was subjected to various analyzes and studies that showed its beneficial effects on cancer such as reducing cancer cell proliferation, reducing tumor growth, inducing apoptosis, reducing cancer risk in diabetic patients, or reducing

PHYSIOLOGICAL RESEARCH • ISSN 1802-9973 (online) - an open access article under the CC BY-NC-ND 4.0 license (c) 2021 Institute of Physiology of the Czech Academy of Sciences, Prague, Czech Republic Fax +420 241062 164, e-mail: physres@fgu.cas.cz, www.biomed.cas.cz/physiolres 
likelihood of relapse (Saraei et al. 2019).

In this review, we present the anticancer activity of MTF highlighting the importance of the AMPK/mTOR pathway in the cancer process. We discuss the possible mechanism of action of MTF on cancer via AMPK/mTOR pathway as well as the potential antiangiogenic effect and induction of apoptosis.

\section{Metformin: biology and clinical use}

MTF is a semisynthetic biguanide derived from the herbaceous plant Galega officinalis (Saraei et al. 2019). In 1957, the U.S. Food and Drug Administration indicated MTF as the first-line therapy of DM2 (Zi et al. 2017). MTF is frequently used as an adjuvant treatment for polycystic ovarian syndrome, metabolic syndrome, and in some cases also tuberculosis (Chen et al. 2020). However, other pleiotropic effects of MTF have also been demonstrated. It has been described the potential use of low doses of MTF in combination with low doses of 2-deoxyglucose in the treatment of polycystic kidneys (Zhao et al. 2019). Some authors observed beneficial effect of MTF on reduction the risk of fractures in patients with DM2 (Jackuliak et al. 2019) and it has been shown, that MTF also improves the myocardial function through cellular glucose and lipid metabolism in patients with or without DM2 (Dziubak et al. 2018). Current studies are examining in particular MTF's effect on ageing and cancer. Figure 1 summarize the various diseases where MTF can have a beneficial effect.

Clinical experience has raised almost no doubts about the safety of MTF. Sometimes in extreme overdose, MTF causes an increase in lactic acid. Therefore, the use of MTF has been discouraged in patients with risk factors for lactic acidosis (Flory et al. 2020). The bioavailability of MTF after oral use is $40-60 \%$ and about $90 \%$ of MTF is excreted via the kidneys within $24 \mathrm{~h}$. The common side effects of MTF are gastrointestinal distress, such as anorexia, nausea, or diarrhea (Stage et al. 2015).

MTF is introduced into the cell via organic cation transporters (OCT) and acts in the liver through stimulation of adenosine-monophosphate (AMP)activated protein kinase (AMPK). MTF inhibits mitochondrial complex I, preventing mitochondrial adenosine-triphosphate (ATP) production, thus increasing cytoplasmic ADP:ATP and AMP:ATP ratios (Rena et al. 2017). If AMP:ATP ratio is increased due to metabolic stress conditions, such as hypoxia or glucose deficiency, AMPK is activated. This means that increase in AMP in the cell activates AMPK. Subsequently, AMPK inhibits gluconeogenic gene transcription and moreover, it inhibits lipogenesis which improves insulin sensitivity (Podhorecka et al. 2017). Thus, MTF increases glucose uptake in muscle cells which leads to a decrease in glucose and insulin blood levels. It was indicated that MTF also increase glucose utilization in the intestine and stimulate glucagon-like peptide-1 (GLP-1) secretion (Foretz et al. 2014).

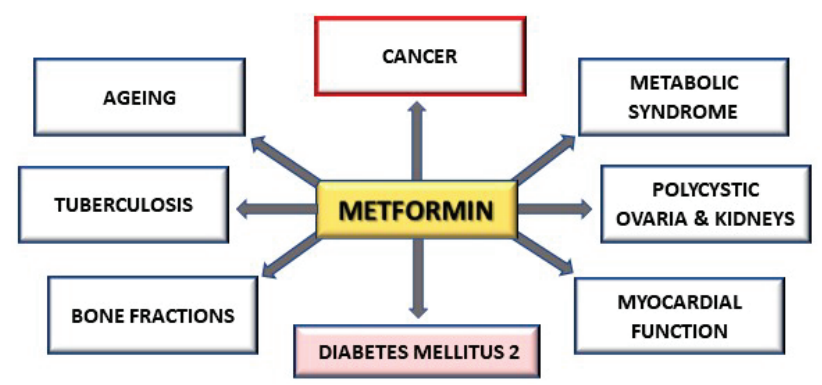

Fig. 1. The various diseases where MTF has a beneficial effect.

\section{Structure and function of AMPK and mTOR}

In general, MTF exerts its effects through AMPK activation. AMPK is a serine/threonine protein kinase and in mammals, there are seven subunit isoforms including two $\alpha$ - subunits, two $\beta$ - subunits, and three $\gamma$-subunits. The $\alpha$-subunits have a catalytic activity, the $\beta$-subunits act as a scaffold to bind $\alpha$ and $\gamma$-subunits to form a functional AMPK heterotrimeric complex, and $\gamma$ - subunits have a regulatory function (Sanli et al. 2014). AMPK is known as a cellular energy sensor to restore energy homeostasis at cell levels in conditions of metabolic stress that reduce ATP levels (Hardie et al. 2012). AMPK is activated by AMP/ADP-dependent and AMP/ADP-independent mechanism. When ATP bound at the regulatory $\gamma$-subunit of AMPK is displaced by AMP, it causes conformational changes which promote phosphorylation of AMPK $\alpha$-subunit at threonine-172. Under metabolic stress conditions, the liver kinase B1 (LKB1) is the main activator of AMPK. AMPK is also activated through $\mathrm{Ca}^{2+} /$ calmodulin-dependent protein kinase 2 (CaMKK2) that is stimulated by increasing levels of intracellular $\mathrm{Ca}^{2+}$ through glucose starvation, and DNA damage, which represent AMP-independent mechanisms. (Hardie et al. 2001, Vara-Ciruelos et al. 2019). The new data have shown, that MTF can activates AMPK also through the lysosomal pathway (Jia et al. 2020). AMPK is described as a kinase that directly 
phosphorylates and inhibits acetyl-coA carboxylase-1, acetyl-coA carboxylase-2 (ACC1, ACC2) and 3-hydroxy3-methyl-glutaryl-coA reductase (HMG-CoA). It induces fatty acid (FA) $\beta$-oxidation in mitochondria and represses expression of lipogenic enzymes (Galdieri et al. 2016). AMPK translocates intracellular vesicles containing glucose transporter type 4 (GLUT4). Based on this, AMPK increases glucose absorption in skeletal muscle. Increase of insulin inhibits AMPK through its direct phosphorylation by protein kinase B (Akt) (Jeon 2016). Table 1 summarizes general functions of AMPK. AMPK also regulates cell growth by phosphorylating multiple downstream targets. One of those targets is the mammalian target of rapamycin (mTOR) (Sanli et al. 2014).

Table 1. General functions of AMPK (Lyons et al. 2018).

\begin{tabular}{ll}
\hline GLUCOSE & $\uparrow$ glycolysis, $\downarrow$ glycogenesis \\
& $\uparrow$ glucose uptake, \\
& $\downarrow$ gluconeogenesis \\
\hline LIPID & $\uparrow \beta$-oxidation, \\
& $\downarrow$ cholesterol biosynthesis \\
& $\uparrow$ lipolysis, $\downarrow$ lipogenesis \\
\hline MITOCHONDRIA & $\uparrow$ oxidative metabolism, \\
& $\uparrow$ mitophagy, \\
& $\uparrow$ autophagy \\
\hline
\end{tabular}

mTOR is a serine/threonine protein kinase that exists in two distinct protein complexes known as mTOR complex 1 (mTORC1) and 2 (mTORC2) where it forms the catalytic subunit. mTOR is a mediator of the phosphatidylinositol-3-kinase (PI3K)- protein kinase B (Akt) signaling pathway, which respond to metabolic and genotoxic stresses and execute adaptive mechanism to cell survival (Zaidi et al. 2019, Zoncu et al. 2011). mTORC1 plays a key role in regulating the growth and division of cells. It promotes protein synthesis through the phosphorylation of p70S6 kinase (p70S6K) and 4E-binding proteins (4E-BP) and de novo lipid synthesis through the sterol responsive element binding protein (SREBP) transcription factors. Moreover, mTORC1 induces glucose uptake through hypoxia-inducible factor $1 \alpha$ (HIF-1 $\alpha$ ) and was found to suppress protein breakdown in order to grow and divide of cells (Kim 2011, Saxton et al. 2017).

\section{Potential mechanism of metformin anticancer activity}

Most epidemiological data suggest that MTF has anticancer potential and offers a lot of benefits for cancer patients. According to the literature, the anticancer activity of MTF probably results from insulin-dependent and insulin-independent mechanism. In the case of the insulin-dependent mechanism, the glucose uptake in the muscle cells caused by MTF leads to a decrease in blood glucose levels and subsequently insulin levels. Glucose and insulin are two well-known promoters of tumor cell proliferation caused by insulin (I) and insulin-like growth factor 1 (IGF-1) (Zi et al. 2017). A recent study on human hepatocellular carcinoma cell line demonstrated a significant reduction of IGF-1 receptors after $24 \mathrm{~h}, 48 \mathrm{~h}$, and $72 \mathrm{~h}$ of MTF treatment $(400 \mu \mathrm{mol} / \mathrm{l})$ in vitro (Vacante et al. 2019). Decreasing the insulin level by MTF may lower the activity of insulin receptor substrate 1 (IRS-1) which results from reduced number of insulin receptors on the cell membrane, thus inactivating I/IGF signaling pathway and preventing a neoplastic activity of cells (Podhorecka et al. 2017).

Several studies reported MTF anticancer effects due to activation of ataxia telangiectasia mutated (ATM) and liver kinase B1 (LKB1). Both are tumor suppressor proteins that play a role in regulating the cellular cycle (Cantoria et al. 2014). It has been shown that loss of LKB1 overactivates mTOR signaling pathway and promotes proliferation in human glioblastoma cells (Zhang et al. 2019). ATM activation causes phosphorylation of LKB1 and thereby activates AMPK, which prevents protein synthesis and cell growth by inhibition of mTOR activity via insulin-independent mechanism. Study on mouse ASZ cells (basal cell carcinoma line resistant to photodynamic therapy) has shown that MTF treatment with concentrations $\geq 75 \mu \mathrm{M}$ for $24 \mathrm{~h}$ induced a significant decrease in cell survival, increased pAMPK levels, thus suppressing the mTOR (Mascaraque et al. 2020). Reduction of mTOR activity reduces the levels of ribosomal S6 kinase factors, thereby decreasing protein synthesis and cell proliferation (Whitburn et al. 2017). Suppression of HIF-1 $\alpha$ by AMPK upon mTOR inhibition silences the Warburg effect (Ciccarese et al. 2019).

AMPK inhibits mTOR activity through two signaling pathways. First one is associated with tuberous sclerosis complex 2 (TSC2). AMPK may activate TSC2, the GTPase-activating protein that forms a complex with TSC1. This complex inhibits the activity of Ras homolog 
enriched in brain (Rheb) and mTOR, therefore blocking mTORC1 activation (Gwinn et al. 2008, Howell et al. 2017). Second pathway relies on a direct phosphorylation and inhibition of regulatory-associated protein of mTOR
(RAPTOR), a scaffold protein of mTORC1 complex (Efeyan et al. 2010). Figure 2 summarizes the role of AMPK activation through MTF performs potential anticancer activity.

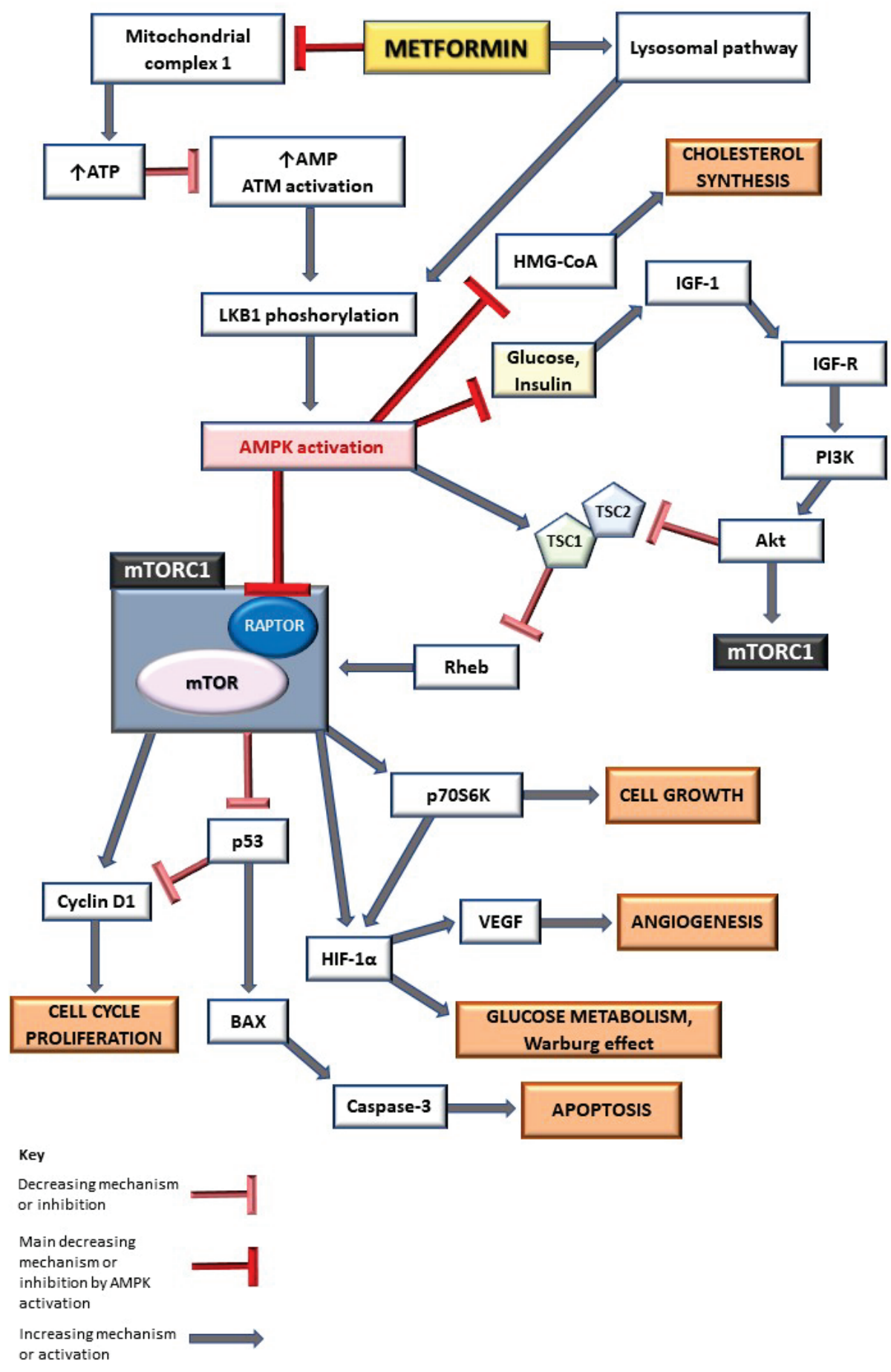

Fig. 2. The role of MTF in metabolism and cancer process through AMPK/mTOR signaling pathway. AMPK activation inhibits mTORC1, leading to decreasing of cell growth, angiogenesis and Warburg effect, and increasing of apoptosis. ATP adenosine-triphosphate, AMP adenosine-monophosphate, ATM ataxia telangiectasia mutated, LKB1 liver kinase B1, AMPK adenosine-monophosphate- activated protein kinase, HMG-CoA $\beta$-Hydroxy $\beta$-methylglutaryl-coenzyme-A, IGF-1 insulin-like growth factor 1 , IGF-R insulin-like growth factor receptor, PI3K phosphatidylinositol-3-kinase, Akt protein kinase B, mTORC1 mammalian target of rapamycin complex 1, TSC1,2 tuberous sclerosis complex 1,2, Rheb Ras homolog enriched in brain, RAPTOR regulatory-associated protein of mTOR, mTOR mammalian target of rapamycin, p53 tumor suppressor protein, p70S6K p70S6 kinase, HIF-1a hypoxia-inducible factor 1a, VEGF vascular endothelial growth factor, BAX BCL-2 associated $\mathrm{X}$ protein. 


\section{Metformin and apoptosis}

Apoptosis is the process of programmed cell death with specific morphological and biochemical features. There exist many extrinsic and intrinsic pathways that can induce the process of apoptosis. One of the intrinsic molecular systems regulating the apoptotic process is BCL-2/BAX. BCL-2 (B-cell lymphoma 2) is an inhibitor of apoptosis promoting the survival of cancer cells and supporting their division. On the other hand, BAX (BCL-2 associated $\mathrm{X}$ protein) is a proapoptotic protein which creates membrane permeabilizing pores. The direct activator of BAX is the tumor suppressor protein $\mathrm{p} 53$, which is crucial coordinator for controlling life and death of a cells. (Delhalle et al. 2003, Knudson et al. 1997). Study on human bile duct cancer cells in vitro demonstrated that MTF $(0.5 \mathrm{mg} / \mathrm{ml})$ significantly augmented the expression of BAX protein and reduced the expression of BCL-2 after $24 \mathrm{~h}$ and $48 \mathrm{~h}$ treatment (Lee et al. 2019). A key protease inhibitor in apoptosis is caspase-3, the final implement of the apoptotic process. In vitro cultivation of A172 human glioma cells with MTF (0.1.1 and $10 \mathrm{mmol} / \mathrm{l})$ for $48 \mathrm{~h}$ increased the activity of caspase-3, increased the expression of BAX protein and decreased $\mathrm{BCl}-2$ expression in dose-dependent manner (Xiong et al. 2019). Study on human esophageal squamous cancer cells in vitro has shown the same effect of MTF treatment at various doses $(0.5,10$ and $20 \mathrm{mmol} / \mathrm{l})$. MTF induced the apoptosis of cells by activation of caspase-3 (Fan et al. 2019). MTF treatment of human gallbladder adenocarcinoma cells blocked the G0 to G1 cellular transition, which was accompanied by reduction of cyclin D1 (Yamashita et al. 2020). The current studies demonstrate that the effect of MTF on apoptosis induction may be associated with the AMPK/mTOR signaling pathway and may reduce the expression of G1 cyclins (Gao et al. 2016).

\section{Metformin and angiogenesis}

Angiogenesis in cancer is an unregulated process which is crucial for tumor cells as it provides nutrients, oxygen, and other growth factors essential for further survival of cancerous tissue and allows removal of waste products. Expanding tumor results in a hypoxia in the center of the tumor which is a known inducer of expression of proangiogenic factors through HIF-1 $\alpha$. Hypoxia also provides angiogenic and metastatic signals. The most important proangiogenic molecule stimulated by hypoxia is a vascular endothelial growth factor (VEGF) (Tonini et al. 2003). It has been shown that MTF at $0.01 \mathrm{mM}$ concentration decreased VEGF levels in rat granulosa cells in vitro (Di Pietro et al. 2020). Canine mammary tumor cells treated with MTF displayed a decreased protein and gene expression of VEGF and HIF-1 $\alpha$ (Moschetta et al. 2019). It has been demonstrated that mTORC1 activity is necessary for the expression of HIF- $1 \alpha$ and inhibition of mTORC1 leaded to decrease of HIF- $1 \alpha$ (Tadakawa et al. 2015). Based on these findings, we can speculate that MTF has antiangiogenic effects due to inhibition of mTORC1. In the process of tumor angiogenesis, the presence of caveolar constituents composed of caveolin-1 (cav-1) and caveolin-2 (cav-2) has been reported. It was observed that systemic injections of $120 \mathrm{mg} / \mathrm{kg}$ MTF in xenograft breast tumor models in vivo increased cav-1 expression which in turn suppressed the tumor angiogenesis (Yang et al. 2018). However, cav-1 plays different roles in various cancer types. Sometimes, it has a tumor-promoting function, sometimes a tumor-suppressing. Thus, the role of cav-1 in cancer process is still controversial (Fu et al. 2017).

\section{Metformin and clinical trials in therapy of cancer}

To date, several clinical studies have been performed to investigate the potential of MTF anti-cancer effects. One of the most important and still ongoing clinical trial is NCT01101438. It is a three-phase, triplemasked randomized study involving 3,649 participants (18-74 years old) to date. In this study, MTF is compared to placebo as an adjunct to standard adjuvant treatment of primary stage non-metastatic breast cancer. Patients take metformin hydrochloride orally two times a day (weeks 1 to 4 once a day) and continue the treatment for 5 years after diagnosis. So far, the results of an ongoing study have shown that MTF has improved survival without invasive disease (progression-free survival). The study should be completed by February 2022 (https:/clinicaltrials.gov/ct2/show/NCT01101438). The MTF effect on breast cancer patients was also studied in a two-phase, open label, single group assignment study NCT01266486. Oral metformin hydrochloride was administered to 41 participants (18 years and older) once daily for 14-21 days in addition to standard neoadjuvant chemotherapy. The aim of the study was to identify potential biomarkers of response to MTF therapy by immunohistochemical analysis. The outcomes 
demonstrated the ability of MTF to induce the effects of p70S6K, 4E-BP-1, and AMPK phosphorylation which confirms the possible anticancer activity mediated by the AMPK pathway. Study was completed in May 2014 (https://clinicaltrials.gov/ct2/show/NCT01266486).

\section{Conclusion}

Recent scientific studies and clinical trials indicate that the pleiotropic effects of MTF play a significant role in the treatment of various diseases, including cancer. Many studies suggest that reduction in circulating insulin levels and growth factors derived therefrom, AMPK activation, and mTOR inhibition may lead to antiproliferative, antiangiogenic and, thus, anticancer activity of MTF. In general, AMPK/mTOR pathway plays a crucial role in the cancer process and MTF seems to be a very promising influencer. However, the key cellular and molecular factors of this MTF's effect are still not definitely described, therefore for an individual therapeutic approach in the treatment and prevention of cancer further observations and investigations are needed.

\section{Conflict of Interest}

There is no conflict of interest.

\section{Acknowledgement}

Grant support: UK/304/2020 and APVV/18/0103.

\section{References}

ABDEL-WAHAB AF, MAHMOUD W, AL-HARIZY R: Targeting glucose metabolism to suppress cancer progression: prospective of anti-glycolytic cancer therapy. Pharmacol Res 150: 104511, 2019. https://doi.org/10.1016/j.phrs.2019.104511

BLOCK KI, GYLLENHAAL C, LOWE L, AMEDEI A, AMIN ARMR, AMIN A, AQUILANO K, ARBISER J, ARREOLA A, ARZUMANYAN A, et al: Designing a broad-spectrum integrative approach for cancer prevention and treatment. Semin Cancer Biol 35: 276-304, 2015. https://doi.org/10.1016/j.semcancer.2015.09.007

CANTORIA MJ, PATEL H, BOROS LG, MEUILLET EJ: Metformin and pancreatic cancer metabolism. Pancreatic cancer-insights into molecular mechanisms and novel approaches to early detection and treatment. London, UK: IntechOpen, 2014. https://doi.org/10.5772/57432

CICCARESE F, ZULATO E, INDRACCOLO S: LKB1/AMPK Pathway and drug response in cancer: A therapeutic perspective. Oxid Med Cell Longev: 8730816, 2019. https://doi.org/10.1155/2019/8730816

DELHALLE S, DUVOIX A, SCHNEKENBURGER M, MORCEAU F, DICATO M, DIEDERICH M: An introduction to the molecular mechanisms of apoptosis. Ann NY Acad Sci 1010: 1-8, 2003. https://doi.org/10.1196/annals.1299.001

Di PIETRO M, VELAZQUES C, MATZKIN ME, FRUNGIERI MB, PENA MG, ZUNIGA I, PASCUALI N, IRUSTA G, BIANCHI MS, PARBORELL F, DALHIA A: Metformin has a direct effect on ovarian cells that is dependent on organic cation transporters. Mol Cell Endocrinol 499: 110591, 2020. https://doi.org/10.1016/j.mce.2019.110591

DZUIBAK A, WOJCICKA G, WOJTAK A, BELTOWSKI J: Metabolic effect of metformin in the failing heart. Int J Mol Sci 19: 2869, 2018. https://doi.org/10.3390/ijms19102869

EFFEYAN A, SABATINI DM: mTOR and cancer: Many loops in one pathway. Curr Opin Cell Biol 22: 169-176, 2010. https://doi.org/10.1016/j.ceb.2009.10.007

FAN H, YU X, ZOU Z, ZHENG W, DENG X, GUO L, JIANG W, ZHAN Q, LU S-H: Metformin suppresses the esophageal carcinogenesis in rats treated with NMBzA through inhibiting AMPK/mTOR signaling pathway. Carcinogenesis 40: 669-679, 2019. https://doi.org/10.1093/carcin/bgy160

FLORY JH, HENNESSY S, BAILEY CJ, INZUCCHI SE: Reports of actic acidosis attributed to metformin, 2015-2018. Diabetes Care 43: 244-246, 2020. https://doi.org/10.2337/dc19-0923

FORETZ M, GUIGAS B, BERTRAND L, POLLAK M, VIOLLET B: Metformin from mechanism of action to therapies. Cell Metab 20: 953-966, 2014. https://doi.org/10.1016/j.cmet.2014.09.018

FU P, CHEN F, PAN Q, ZHAO X, ZHAO C, CHO WC, CHEN H: The different functions and clinical significances of caveolin-1 in human adenocarcinoma and squamous cell carcinoma. Onco Targets and Therapy 10: 819-835, 2017. https://doi.org/10.2147/OTT.S123912 
GALDIERI L, GATLA H, VANCUROVA I, VANCURA A: Activation of AMP-activated protein kinase by metformin induces protein acetylation in prostate and ovarian cancer cells. J Biol Chem 291: 25154-25166, 2016. https://doi.org/10.1074/jbc.M116.742247

GAO ZY, LIU Z, BI MH, ZHANG JJ, HAN ZQ, HAN X, WANG HY, SUN GP, LIU H: Metformin induces apoptosis via a mitochondria-mediated pathway in human breast cancer cells in vitro. Exp Ther Med 11: 1700-1706, 2016. https://doi.org/10.3892/etm.2016.3143

GWINN DM, SHACKELFORD DB, EGAN DF, MIHAYLOVA MM, MERY A, VASQUEZ DS, TURK BE, SHAW RJ: AMPK phosphorylation of raptor mediates a metabolic checkpoint. Mol Cell 30: 214-226, 2008. https://doi.org/10.1016/j.molcel.2008.03.003

HARDIE DG, HAWLEY SA: AMP-activated protein kinase: the energy charge hypothesis revisited. Bioessays 23: 1112-1119, 2001. https://doi.org/10.1002/bies.10009

HARDIE DG, ROSS FA, HAWLEY SA: AMPK: a nutrient and energy sensor that maintains energy homeostasis. Nat Rev Mol Cell Biol 13: 251-262, 2012. https://doi.org/10.1038/nrm3311

HOWELL JJ, HELlBERG K, TURNER M, TALBITT G, KOLAR MJ, ROSS DV, HOXHAJ G, SAGHATELIAN A, SHAW RJ, MANNING BD: Metformin inhibits hepatic mTORC1 signaling via dose-dependent mechanisms involving AMPK and the TSC complex. Cell Metab 25: 463-471, 2017. https://doi.org/10.1016/j.cmet.2016.12.009

CHEN K, LI Y, GUO Z, ZENG Y, ZHANG W, WANG H: Metformin: current clinical applications in nondiabetic patients with cancer. Aging (Albany NY) 12: 3993-4009, 2020. https://doi.org/10.18632/aging.102787

JACKULIAK P, KUZMA M, PAYER J: Effect of antidiabetic treatment on bone. Physiol Res 68 (Suppl 2): 107-120, 2019. https://doi.org/10.33549/physiolres.934297

JEON S: Regulation and function of AMPK in physiology and diseases. Exp Mol Med 48: e245, 2016. https://doi.org/10.1038/emm.2016.81

JIA J, BISSA B, BRECHT L, ALLERS L, CHOI SW, GU Y, ZBINDEN M, BURGE MR, TIMMINS G, HALLOWS $\mathrm{K}$, BEHRENDS $\mathrm{CH}$, DERETIC V: AMPK, a regulator of metabolism and autophagy, is activated by lysosomal damage via a novel galectin-directed ubiquitin signal transduction system. Mol Cell 77: 1-19, 2020. https://doi.org/10.1016/j.molcel.2019.12.028

KIM WJ: Is 5'-AMP-activated protein kinase both Jekyll and Hyde in bladder cancer? Int neurourol J 19: 55-66, 2015. https://doi.org/10.5213/inj.2015.19.2.55

KNUDSON CM, KORSMEYER SJ: Bcl-2 and Bax function independenty to regulate cell death. Nat Gen 16: 358-363, 1997. https://doi.org/10.1038/ng0897-358

LEE J, HONG EM, KIM JH, PARK SW, KOH DH, CHOI MH, JANG HJ, KAE SH: Metformin induces apoptosis and inhibits proliferation through the AMP-activated protein kinase and insulin-like growth facror 1 receptor pathways in the bile duct cancer cells. J Cancer 10: 1734-1744, 2019. https://doi.org/10.7150/jca.26380

LYONS C.L, ROCHE H. M: Nutritional modulation of AMPK-impact upon metabolic-inflammation. Int J Mol Sci 19: 3092, 2018. https://doi.org/10.3390/ijms19103092

MASCARAQUE M, DELGADO-WICKE P, NUEVO-TAPIOLES C, GRACIA-CAZANA T, ABARCA-LACHEN E, GONZALES S, CUEZVA JM, GILABERTE Y, JUARRANZ A: Metformin as an adjuvant to photodynamic therapy in resistant basal cell carcinoma cells. Cancers (Basel) 12: 668, 2020. https://doi.org/10.3390/cancers12030668

MOSCHETTA MG, LEONEL C, MASCHIO-SIGNORINI LB, BORIN TF, GELALETI GB, JARDIM-PERASSI BV, FERREIRA LC, SONEHARA NM, CARVALHO LGS, HELLMEN E, CAMPOS ZUCCARI D: Evaluation of angiogenesis process after metformin and LY294002 treatment in mammary tumor. Anticancer Agents Med Chem 19: 655-666, 2019. https://doi.org/10.2174/1871520619666181218164050

PODHORECKA M, IBANEZ B, DMOSZYNSKA A: Metformin - its potential anti-cancer and anti-aging effects. Postepy Hig Med Dosw 71: 170-175, 2017. https://doi.org/10.5604/01.3001.0010.3801

RENA G, HARDIE DG, PEARSON E: The mechanisms of action of metformin. Diabetologia 60: 1577-1585, 2017. https://doi.org/10.1007/s00125-017-4342-Z

SANLI T, STEINBERG GR, SINGH G, TSAKIRIDIS T. AMP-activated protein kinase (AMPK) beyond metabolism: a novel genomic stress sensor participating in the DNA damage response pathway. Cancer Biol Ther 15: 156-169, 2014. https://doi.org/10.4161/cbt.26726 
SAXTON RA, SABATINI DM: mTOR signaling in growth, metabolism, and disease. Cell 168: 960-976, 2017. https://doi.org/10.1016/j.cell.2017.02.004

SARAEI P, ASADI I, KAKAR M A, MORADI-KOR N: The beneficial effects of metformin on cancer prevention and therapy: a comprehensive review of recent advances. Cancer Manag Res 11: 3295-3313, 2019. https://doi.org/10.2147/CMAR.S200059

SCHNEIDER MB, MATSUZAKI H, HAORAH J, ULRICH A, STANDOP J, DING XZ, ADRIAN TE, POUR PM: Prevention of pancreatic cancer induction in hamsters by metformin. Gastroenterol 120: 1263-1270, 2001. https://doi.org/10.1053/gast.2001.23258

STAGE TB, BROSEN K, CHRISTENSEN MM: A comprehensive review of drug-drug interactions with metformin. Clin Pharmacokinet 54: 811-824, 2015. https://doi.org/10.1007/s40262-015-0270-6

TADAKAWA M, TAKEDA T, LI B, TSUIJI K, YAEGASHI N: The anti-diabetic drug metformin inhibits vascular endothelial growth factor expression via the mammalian target of rapamycin complex 1/hypoxia-inducible factor-1 $\alpha$ signaling path-way in ELT-3 cells. Mol Cell Endocrinol 399: 1-8, 2015. https://doi.org/10.1016/j.mce.2014.08.012

TONINI T, ROSSI F, CLAUDIO P: Molecular basis of angiogenesis and cancer. Oncogene 22: 6549-6556, 2003. https://doi.org/10.1038/sj.onc.1206816

VACANTE F, SENESI P, MONTESANO A, PAINI S, LUZI L, TERRUZZI I: Metformin counteracts HCC progression and metastasis enhancing KLF6/p21 expression and downregulating the IGF axis. Int J Endocrinol 2019: 7570146, 2019. https://doi.org/10.1155/2019/7570146

VARA-CIRUELOS D, DANDAPANI M, RUSSELL FM, GRZES KM, ATRIH A, FORETZ M, VIOLLET B, LAMONT DJ, CANTRELL DA, HARDIE DG: Phenformin, But Not Metformin, Delays Development of T Cell Acute Lymphoblastic Leukemia/Lymphoma via Cell-Autonomous AMPK Activation. Cell Rep 27: 690-698, 2019. https://doi.org/10.1016/j.celrep.2019.03.067

VOGELSTEIN B, PAPADOUPOULOS N, VELCULESCU VE, SHOU S, DIAZ LA Jr, KINZLER KW: Cancer genome landscapes. Science 339: 1546-1558, 2013. https://doi.org/10.1126/science.1235122

WHITBURN J, EDWARDS CM, SOORIAKUMARAN P: Metformin and prostate cancer: a new role for an old drug. Curr Urol Rep 18: 46, 2017. https://doi.org/10.1007/s11934-017-0693-8

XIONG ZS, GING SF, SI W, JIANG T, LI QL, WANG TJ, WU RY, JIANG K: Effect of metformin on cell proliferation, apoptosis, migration and invasion in A172 glioma cells and its mechanisms. Mol Med Rep 20: 887-894, 2019. https://doi.org/10.3892/mmr.2019.10369

YAMASHITA T, KATO K, FUJIHARA S, IWAMA H, MORISHITA A, YAMANA H, KOBAYASHI K, KAMADA H, CHIYO T, KOBARA H, TSUTSUI K, OKANO K, SUZUI Y, MASAKI T: Anti-diabetic drug metformin inhibits cell proliferation and tumor growth in gallbladder cancer via G0/G1 cell cycle arrest. Anti-cancer drugs 31: 231-240, 2020. https://doi.org/10.1097/CAD.0000000000000870

YANG L, MA B, SUN G, DONG CH, MA B: Antiproliferative and antiangiogenic effects of metformin on multidrugresistant MCF-7 cells. Int J Clin Exp Med 11: 6776-6783, 2018.

ZAIDI S, GANDHI J, JOSHI G, SMITH NL, KHAN SA: The anticancer potential of metformin on prostate cancer. Prostate Cancer Prostatic Dis 22: 351-361, 2019. https://doi.org/10.1038/s41391-018-0085-2

ZHANG K, WANG J, WANG J, LUH F, LIU X, YANG L, LIU Y-R, SU L, YANG Y-CH SH, CHU P, YEN Y: LKB1 deficiency promotes proliferation and invasion of glioblastoma trough activation of mTOR and focal adhesion kinase signaling pathways. Am J Cancer Res 9: 1650-1663, 2019.

ZHAO J, MA Y, ZHANG Y, FU B, WU X, LI Q, CAI G, CHEN X, BAY X-Y: Low-dose 2-deoxyglucose and metformin synergically inhibit proliferation of human polycystic kidney cells by modulating glucose metabolism. Cell Death Discov 5: 76, 2019. https://doi.org/10.1038/s41420-019-0156-8

ZI F, ZI H, LI Y, HE J, SHI Q, CAI Z: Metformin and cancer: An existing drug for cancer prevention and therapy (Review). Oncol Lett 15: 683-690, 2018. https://doi.org/10.3892/ol.2017.7412

ZONCU R, EFEYAN A, SABATINI DM: mTOR: form growth signal integration to cancer, diabetes and ageing. Nat Rev Mol Cell Biol 12: 21-35, 2011. https://doi.org/10.1038/nrm3025 